\title{
Patryk Olszak
}

Uniwersytet Marii Curie-Skłodowskiej w Lublinie

olszakp93@wp.pl

\section{Przestępstwo utrwalania i rozpowszechniania wizerunku nagiej osoby lub osoby w trakcie czynności seksualnej}

The Crime of Fixing and Distributing the Image of a Naked Person or a Person During Sexual Activity

\section{STRESZCZENIE}

Celem niniejszego opracowania jest analiza przestępstwa utrwalania i rozpowszechniania wizerunku nagiej osoby lub osoby w trakcie czynności seksualnej. Na jej podstawie autor sformułuje odpowiedź na pytanie, czy wprowadzenie przestępstwa określonego w przepisie art. 191a k.k. było zabiegiem słusznym i koniecznym. Ponadto oceni, czy analizowana regulacja stała się, zgodnie z założeniami ustawodawcy, remedium na przeciwdziałanie wzrostowi tego zjawiska.

Słowa kluczowe: utrwalanie wizerunku; rozpowszechnianie; nagość; przestępstwo

Coraz popularniejsze staje się upublicznianie nagich zdjęć lub nagrań bez zgody, a często także bez wiedzy osób sfotografowanych bądź nagrywanych. Wraz z postępem techniki i ogólnodostępną wymianą informacji w internecie umieszczanie cudzych zdjęć czy filmów stało się zachowaniem powszechnym, wymagającym odrębnego uregulowania w polskim Kodeksie karnym. Nagminność tego typu zachowań spowodowała konieczność przeciwdziałania temu zjawisku ${ }^{1}$.

Ustawą z dnia 5 listopada 2009 r. o zmianie ustawy - Kodeks karny i niektórych innych ustaw ${ }^{2}$ do polskiego Kodeksu karnego wprowadzono przepis art. 191a. Wszedł on w życie po upływie 6 miesięcy od dnia ogłoszenia ustawy, a więc w dniu 8 czerwca 2010 r. Został on umieszczony w rozdziale XXIII Kodeksu

1 M. Mozgawa, [w:] Kodeks karny. Praktyczny komentarz, red. M. Mozgawa, Warszawa 2010, s. 391.

2 T.j. Dz.U. z 2009 r., nr 206, poz. 1589. 
karnego zatytułowanym Przestępstwa przeciwko wolności. Zgodnie z treścią art. 191a k.k., „kto utrwala wizerunek nagiej osoby, lub osoby w trakcie czynności seksualnej, używając w tym celu wobec niej przemocy, groźby bezprawnej lub podstępu, albo wizerunek nagiej osoby lub osoby w trakcie czynności seksualnej bez jej zgody rozpowszechnia podlega karze pozbawienia wolności od 3 miesięcy do lat 5. Ściganie następuje na wniosek pokrzywdzonego"3.

Jest to nowy, nieznany wcześniej polskiemu ustawodawstwu, typ czynu zabronionego. Za przedmiot ochrony uznaje się tu swobodę jednostki w zakresie dysponowania jej intymnym wizerunkiem (przedstawiającym daną osobę nago lub podczas czynności seksualnej) ${ }^{4}$. Swobodę tę należy rozumieć jako wolność do niedozwolonego oddziaływania innych ludzi na integralność i swobodę procesu podejmowania decyzji ${ }^{5}$. Dokonując analizy tego przepisu, nie sposób nie uznać słuszności i prawidłowości wprowadzenia tego rodzaju przestępstwa do polskiego ustawodawstwa karnego, niezależnie od tego, jakiego rodzaju racje ustawodawcze były z tym związane i jak duży wpływ miały na to przypadki z praktyki. Dosyć często zdarza się tak, że to właśnie rzeczywistość wywiera wpływ na potrzebę reakcji prawnej przejawiającej się w decyzji ustawodawcy co do wprowadzenia nowych regulacji. W tym przypadku wprowadzenie nowego typu czynu zabronionego może okazać się szczególnie ważne z punktu widzenia osób pokrzywdzonych czynami opisanymi w art. 191a k.k. Pokrzywdzeni w związku z wnioskowym trybem ścigania mogą sami decydować o tym, czy chcą ścigania sprawców przestępstwa czy też wolą dochodzić swoich praw na drodze cywilnoprawnej6.

M. Mozgawa oraz K. Nazar-Gutowska dokonali szczegółowej analizy ustawowych znamion tego czynu. Wyniki ich badań obrazują w sposób jasny i klarowny znaczenie omawianej problematyki. Zdaniem autorów każdy z takich typów czynu zabronionego może być przedstawiony jako mający chronić „wolność od zamachów” na jakieś dobro. W opinii M. Mozgawy w takim ujęciu jest pewna logika, jednakże opowiadanie się za nim w sposób niezamierzony mogłoby sprawić, że znaczna część przestępstw stałaby się do siebie podobna (co musiałoby pociągać za sobą pewne konsekwencje prawne) $)^{7}$.

M. Filar uważa natomiast, że indywidualnym przedmiotem ochrony art. 191a k.k. jest wolność decyzyjna człowieka w obszarze intymności związanej z jego sferą seksualizmu, w szczególności wchodzącego w tę sferę prawa do rezygnacji $\mathrm{z}$ tej intymności w związku z eksponowaniem jej przejawów na zewnątrz ${ }^{8}$. Nie

3 M. Mozgawa, [w:] Kodeks karny ..., s. 391.

4 M. Filar, Kodeks karny. Komentarz, Warszawa 2015, s. 920.

5 Ibidem.

6 Ibidem.

7 M. Mozgawa, Odpowiedzialność karna za bezprawne pozbawienie wolności (art. 165 k.k.), Lublin 1995, s. 29.

8 M. Filar, op. cit., s. 921. 
jest to zatem klasyczne przestępstwo seksualne, a jedynie w rozumieniu art. 115 $\S 3$ k.k. jest ono podobne do przestępstw opisanych w rozdziale XXV k.k. M. Filar zwraca uwagę, że w przypadku tego przestępstwa chodzi zarówno o wolność od zastraszania lub stosowania podstępu w celu utrwalania takiego wizerunku, jak i o wolność do decydowania o jego rozpowszechnianiu?.

T. Bojarski z kolei wskazuje, że przedmiotem ochrony jest jeden z aspektów szeroko rozumianej wolności jednostki w postaci swobody zachowań i fizycznej prezentacji swojej osoby w wybranej formie, w określonych warunkach. W jej zakresie mieszczą się takie przejawy wolności jednostki, jak prawo do czynności seksualnych w ramach intymnej sfery życia bez upowszechniania własnych przeżyć fizycznych i emocjonalnych ${ }^{10}$.

Zachowanie sprawcy omawianego przestępstwa polega na utrwalaniu wizerunku nagiej osoby w trakcie czynności seksualnej albo rozpowszechnianiu takiej treści bez zgody uprawnionego. W tym miejscu zasadne będzie poddanie pod rozważenie istoty samego terminu „nagość”. Wyróżnia się dwa rodzaje nagości: całkowitą lub częściową. Z nagością całkowitą mamy do czynienia wówczas, kiedy ktoś jest zupełnie pozbawiony odzieży. Istotne jest to, że jeżeli człowiek posiada na sobie jakiekolwiek elementy dodatkowe, takie jak np. biżuteria czy nakrycie głowy, to nie powoduje tym samym zanegowania stanu całkowitej nagości. Nagość częściowa występuje, gdy osoba pozbawiona jest odzieży osłaniającej zwłaszcza narządy płciowe ${ }^{11}$. Dokonując analizy terminu „nagość”, należy wyróżnić nagość naturalną (np. kobieta podczas porodu), nagość dobrowolną (np. dobrowolne przebywanie na plaży naturystycznej), a także nagość przymusową, która może, ale niekoniecznie musi wynikać z działań bezprawnych - wówczas będzie to nagość legalna (np. rozebranie pacjenta w celu przeprowadzenia badania leczniczego) ${ }^{12}$.

Z kolei mówiąc o czynności seksualnej (w trakcie której osoba zostaje utrwalona), ustawodawca ma na myśli obcowanie płciowe, ale też inną czynność seksualną w rozumieniu art. 197 k.k., a zatem oprócz klasycznego obcowania płciowego zalicza się tutaj różnego rodzaju odmiany, surogaty. Warto jednak tu zakwalifikować działania polegające na kontakcie cielesnym sprawcy z pokrzywdzonym, mające charakter seksualny dla ofiary. W celu wystąpienia obcowania płciowego konieczne jest zaangażowanie w tę czynność organów płciowych chociaż jednej osoby, czyli sprawcy bądź pokrzywdzonego ${ }^{13}$. Do innych czynności seksualnych zaliczamy

9 Ibidem.

10 T. Bojarski, [w:] Kodeks karny. Komentarz, red. T. Bojarski, Warszawa 2013, s. 508.

11 M. Mozgawa, K. Nazar-Gutowska, Utrwalanie lub rozpowszechnianie wizerunku nagiej osoby - art. 191 a k.k. (analiza prawnokarna i praktyka ścigania), [w:] Prawo w działaniu, red. M. Mozgawa, Warszawa 2014, s. 9.

${ }^{12}$ Nagość, www.sjp.pwn.pl/slowniki/nagość [dostęp: 01.05.2017].

13 J. Warylewski, [w:] Kodeks karny. Częśś szczególna. Komentarz do art. 117-221, red. A. Wąsek, t. 1, Warszawa 2006, s. 778. 
m.in. obmacywanie narządów płciowych ofiary czy zmuszanie jej do samogwałtu. Czynności seksualne, o których jest mowa w art. 191a k.k., mogą mieć charakter hetero- lub homoseksualny, poza tym mogą przybierać formę autoerotyzmu ${ }^{14}$. Osoba utrwalana w czasie czynności seksualnej nie musi być koniecznie naga. Możliwe są przecież sytuacje, gdy dokonywana jest czynność seksualna w ubraniu, a organy płciowe nie są widoczne, lecz z utrwalonego wizerunku wynika, że osoba lub osoby biorą udział w czynności seksualnej ${ }^{15}$.

Konieczne jest, aby przy utrwalaniu wizerunku nagiej osoby lub osoby w trakcie czynności seksualnej sprawca używał wobec niej przemocy, groźby bezprawnej lub podstępu. Nie jest jednak niezbędne, aby podstęp był równoczesny z czynnością utrwalania (może bowiem zaistnieć sytuacja, w której sprawca, spodziewając się przybycia gości, instaluje $\mathrm{w}$ ich pokoju urządzenia nagrywające, które w odpowiednim momencie uruchamia, a następnie utrwala nagi wizerunek). Na gruncie art. 191a k.k. chodzi o bezpośrednie użycie siły fizycznej w celu uniemożliwienia oporu ofiary, np. przez jej związanie. Można mówić tylko i wyłącznie o użyciu tej przemocy wobec osoby pokrzywdzonej z jednoczesnym wyłączeniem możliwości przyjęcia, aby przemoc ta była nakierowana na inną osobę albo przeciwko rzeczy ${ }^{16}$.

Skupiając się na samym terminie „podstęp”, uwagę zwrócić należy na jego potoczne rozumienie. Jest to zabieg mający na celu oszukanie kogoś, zmylenie ${ }^{17}$. W doktrynie wyróżnia się podstęp w ujęciu szerszym i węższym ${ }^{18}$. W ujęciu węższym jest to wprowadzenie w błąd lub wykorzystanie błędu ofiary w zakresie przesłanek motywacyjnych. W ujęciu szerszym natomiast jest to zarówno wprowadzenie w błąd ofiary, jak i doprowadzenie jej przez to do stanu, w którym nie może podjąć lub zrealizować decyzji woli ze względu na wyłączenie aparatu decyzyjnego lub ruchowego ${ }^{19}$. Na gruncie przestępstwa utrwalania i rozpowszechniania wizerunku nagiej osoby lub osoby w trakcie czynności seksualnej trzeba opierać się na szerszym, doktrynalnym rozumieniu podstępu ${ }^{20}$. Może dojść do sytuacji, w której dana osoba, pozostając w błędzie, wyrazi zgodę na utrwalenie swojego nagiego wizerunku. Błąd ten może wynikać np. z sytuacji, w której sprawca przekonuje daną osobę, że w aparacie fotograficznym nie ma filmu. Jednakże do podstępu nie zalicza się sytuacji, w której ofiara wyraża zgodę na utrwalenie swojego wizerunku pod wpływem obietnicy małżeńskiej czy korzyści majątkowej. Podstępem nie będzie również jawne utrwalenie wizerunku nagiej osoby w przypadku, kiedy sprawca tej czynności organizuje fikcyjny casting do filmu pornograficznego, oczywiście

\footnotetext{
14 Ibidem.

15 Ibidem.

16 Ibidem.

17 Ibidem, s. 767.

18 Ibidem, s. 778.

19 Ibidem.

20 Ibidem.
} 
bez zamiaru produkcji takiego filmu. Do podstępu nie zalicza się także podania komuś tzw. afrodyzjaków zwiększających popęd płciowy, ponieważ środki te nie wyłączają możliwości podjęcia woli co do zachowań seksualnych, lecz podanie narkotyku wyłączającego świadomość stanowi podstęp ${ }^{21}$. Jako klasyczny przykład może posłużyć tzw. tabletka gwałtu, która w interakcji z alkoholem powoduje wyłączenie świadomości oraz zwiotczenie mięśni na dłuższy czas - kilka godzin. Podanie innej osobie danego środka celem odbycia z nią czynności seksualnej (oraz jednocześnie utrwalanie tego zdarzenia) w rozumieniu Kodeksu karnego niewątpliwie stanowi podstęp oraz implikuje konieczność przyjęcia kumulatywnej kwalifikacji czynu z art. 197 w zb. z art. 191a § 1 k.k. (w zw. z art. 11 § 2 k.k.) 22 .

Wykorzystanie przez sprawcę stanu, w jakim znajduje się naga ofiara (stan nieprzytomności czy poważnego upojenia alkoholowego) i utrwalenie jej wizerunku nie będzie implikować odpowiedzialności z art. 191a k.k. (chyba że sprawca zacznie rozpowszechniać taki wizerunek bez wymaganej zgody). W przypadku, gdy sprawca sam doprowadzi ofiarę np. do stanu nieprzytomności, ów czyn kwalifikować się będzie jako ten opisany w art. 191a k.k. Odmiennym, a zarazem ciekawym przykładem będzie sytuacja, w której sprawca nie ukrywa swoich działań i utrwala wizerunek osoby opalającej się na plaży (nawet pomimo jej protestów). We wskazanym powyżej przykładzie nie możemy mówić o realizacji ustawowych znamion czynu zabronionego. Kwestia odpowiedzialności karnej za tę czynność może pojawić się w przypadku, kiedy tak utrwalony wizerunek zostanie rozpowszechniony ${ }^{23}$.

Sąd Najwyższy w wyroku z dnia 16 lutego 1987 r. stwierdził, że za rozpowszechnianie należy uznać czynienie określonych treści powszechnie dostępnymi, umożliwienie zapoznania się z nimi większej, bliżej nieokreślonej liczbie osób. Przy rozpowszechnianiu wizerunku nagiej osoby możemy mieć do czynienia z dwiema sytuacjami. Po pierwsze z taką, w której ofiara nie wyraża zgody na utrwalenie jej nagiego wizerunku i sprawca dokonuje tej czynności przy użyciu siły. W drugim przypadku zaś, gdy ofiara wyraża zgodę na dokonanie czynności utrwalenia jej nagiego wizerunku, ale nie wyraża zgody na rozpowszechnianie tych zdjęć bądź filmu ${ }^{24}$.

Utrwalenie musi dotyczyć rzeczywistej, realnej osoby. Z punktu widzenia znamienia czasownikowego, czyli rozpowszechniania, bez znaczenia jest, czy sprawca sam zarejestrował wizerunek ofiary czy nabył go od osoby trzeciej. Kwestią najistotniejszą jest to, czy owo rozpowszechnianie odbywa się bez zgody ofiary ${ }^{25}$.

\footnotetext{
21 M. Mozgawa, K. Nazar-Gutowska, op. cit., s. 13.

22 Ibidem.

23 Ibidem, s. 14.

24 Wyrok SN z dnia 16 lutego 1987 r., WR 28/87, OSNKW 1987, nr 9-10, poz. 85.

25 M. Mozgawa, K. Nazar-Gutowska, op. cit., s. 14.
} 
Zdaniem A. Marka przepis ten budzi wiele wątpliwości interpretacyjnych. Trudno byłoby przypisać popełnienie tego przestępstwa artyście, który ukradkiem szkicuje opalającą się obok niego nagą kobietę ${ }^{26}$. Całkiem odmienną kwestię stanowi problem utrwalania (bądź rozpowszechniania) nagiego wizerunku dzieci, a mianowicie tego, od jakiego wieku dziecko może być przedmiotem czynności wykonawczej danego przestępstwa. Jeżeli uznamy, że przedmiotem ochrony jest intymność i prywatność człowieka, to wiek pokrzywdzonego nie ma tutaj najmniejszego znaczenia. Natomiast jeżeli za przedmiot uznamy „wolność decyzyjną człowieka w obszarze intymności związanej z jego sferą seksualizmu”, wówczas przedmiot ochrony będzie naruszony dopiero w momencie, gdy osoba pokrzywdzona miałaby wykształconą sferę wolności, czego z całą pewnością nie posiada jeszcze bardzo małe dziecko ${ }^{27}$.

M. Królikowski i A. Sakowicz uważają, że konieczne jest wykazanie celu działania sprawcy zgodnego z opisem ustawowym oraz objęcie zamiarem bezpośrednim czynności sprawczej prowadzącej do realizacji celu ${ }^{28}$. W przypadku znamienia „,rozpowszechniania” przyjąć należy, tak jak w przypadku innych przestępstw posługujących się danym znamieniem (np. art. 202 k.k.), że w grę może wejść zarówno zamiar bezpośredni, jak i ewentualny ${ }^{29}$.

Przepis art. 191a k.k. stosunkowo często pozostaje w kumulatywnej kwalifikacji z innymi przepisami, np. z art. 197 k.k. (przestępstwo zgwałcenia), art. 198 k.k. (współżycie z osobą o ograniczonej poczytalności), art. 199 k.k. (nadużycie stosunku zależności lub krytycznego położenia), art. $202 \S 1$ k.k. (publiczne prezentowanie treści pornograficznych). Niemniej należy zwrócić uwagę, że może dojść także do utrwalenia wizerunku nagiego dziecka lub dziecka w trakcie czynności seksualnych przez wykorzystanie seksualne czy zgwałcenie ${ }^{30}$. Kumulatywna kwalifikacja czynu występuje ponadto wtedy, kiedy sprawca dopuści się przemocy przy popełnianiu przestępstwa z art. 191a k.k. Praktyka wykazała, że najczęstszy zbieg omawianego przepisu ma miejsce $\mathrm{z}$ art. 190a $§ 1$ k.k. (nękanie) oraz art. 212 $\S 1$ lub 2 (zniesławienie) ${ }^{31}$.

M. Mozgawa oraz K. Nazar-Gutowska przeprowadzili badania empiryczne ${ }^{32}$, z których wynika, że w 2012 r. wystąpiły 252 sprawy z art. 191a k.k. W sprawach tych podjęto następujące decyzje: 102 odmowy wszczęcia postępowania, 105 umorzeń postępowania, 38 spraw skierowano do sądu z aktami oskarżenia, 7 spraw

26 A. Marek, Kodeks karny. Komentarz, Warszawa 2010, s. 441.

${ }^{27}$ M. Mozgawa, K. Nazar-Gutowska, op. cit., s. 15.

${ }^{28}$ M. Królikowski, A. Sakowicz, [w:] Kodeks karny. Komentarz. Czesść szczególna, red. M. Królikowski, R. Zawłocki, t. 1, Warszawa 2013, s. 557.

${ }^{29}$ Ibidem.

${ }^{30}$ Ibidem.

${ }^{31}$ Ibidem.

32 M. Mozgawa, K. Nazar-Gutowska, op. cit., s. 19. 
załatwiono w inny sposób (3 sprawy - zawieszenie postępowania, 3 - skierowanie do sądu rodzinnego, 1 - dołączona do innego postępowania ${ }^{33}$. Największą liczbę spraw odnotowano na terenie apelacji katowickiej (45), warszawskiej (35) oraz gdańskiej (32). Na terenie apelacji lubelskiej w 2012 r. odnotowano 18 takich spraw. W większości przypadków utrwalenie następowało najczęściej przez użycie telefonu komórkowego (30), ukrytej kamery (7), aparatu fotograficznego (2), był też jeden przypadek kamery umieszczonej w długopisie. Rozpowszechnianie miało miejsce najczęściej przy użyciu internetu i telefonu komórkowego. Najpopularniejsze strony internetowe, na których dochodziło do rozpowszechniania nagich zdjęć i filmów, to: www.facebook.pl (31), www.nasza-klasa.pl (11) oraz www.sexfotka.pl (5) ${ }^{34}$.

Jak zauważyli M. Mozgawa i K. Nazar-Gutowska, do najczęstszych sposobów ujawienia przestępstwa należy zawiadomienie pokrzywdzonej osoby (w 201 przypadkach: 172 kobiety i 29 mężczyzn). W 23 przypadkach zawiadomienie złożyła matka pokrzywdzonej, a w 5 -ojciec, zaś 1 zawiadomienie złożył dziadek pokrzywdzonej. Inne osoby, które składały zawiadomienie, to: lekarz/szpital, nauczycielka/ szkoła, ksiądz, kurator sądowy, rada rodziców zespołu szkolno-wychowawczego, pracownik portalu interia.pl. W przeprowadzonych badaniach odnotowano: 9 przypadków utrwalania wizerunku nagiej osoby, 5 przypadków utrwalania wizerunku osoby w trakcie czynności seksualnej, 17 przypadków rozpowszechniania wizerunku nagiej osoby, 8 przypadków rozpowszechniania wizerunku osoby w trakcie czynności seksualnej, 2 przypadki utrwalania i rozpowszechniania wizerunku nagiej osoby, 2 przypadki utrwalania i rozpowszechniania wizerunku nagiej osoby w trakcie czynności seksualnej, 1 przypadek utrwalania i rozpowszechniania wizerunku nagiej osoby i w trakcie czynności seksualnej ${ }^{35}$.

Z przeprowadzonych badań empirycznych wynika, że typowym oskarżonym jest mężczyzna w przedziale wiekowym 31-40 lat. Najczęściej jest to mieszkaniec

Tab. 1. Charakterystyka oskarżonych o popełnienie przestępstwa z art. 191a k.k.

\begin{tabular}{|l|l|l|l|l|}
\hline \multicolumn{1}{|c|}{ Wiek } & \multicolumn{1}{c|}{ Wykształcenie } & \multicolumn{1}{c|}{ Stan cywilny } & \multicolumn{1}{c|}{ Posiadanie dzieci } & \multicolumn{1}{c|}{ Karalność } \\
\hline $17-20-5$ & Podstawowe -6 & Kawaler/panna -23 & Ma dzieci -16 & Karany -8 \\
\hline $21-25-6$ & Zawodowe -12 & Rozwiedziony -3 & Nie ma dzieci -20 & Niekarany -27 \\
\hline $26-30-6$ & Gimnazjalne -2 & Żonaty/mężatka -12 & Brak danych -4 & Brak danych -4 \\
\hline $31-40-13$ & Średnie -11 & Brak danych -2 & & \\
\hline $41-50-7$ & Wyższe -7 & & & \\
\hline $51-60-3$ & Brak danych -2 & & & \\
\hline$>60-0$ & & & & \\
\hline
\end{tabular}

Źródło: opracowanie własne na podstawie: M. Mozgawa, K. Nazar-Gutowska, Utrwalanie lub rozpowszechnianie wizerunku nagiej osoby - art. 191 a k.k. (analiza prawnokarna i praktyka ścigania), [w:] Prawo w działaniu, red. M. Mozgawa, Warszawa 2014, s. 26-27.
33 Ibidem.
34 Ibidem, s. 20.
35 Ibidem, s. 23. 
miasta o wykształceniu zawodowym, stanu wolnego, niekarany. Jednakże równie często oskarżonymi są osoby pracujące i posiadające wykształcenie wyższe. Wśród pokrzywdzonych dominują kobiety. Charakterystyczne jest to, że niemal zawsze sprawca i osoba pokrzywdzona znają się wcześniej i była pomiędzy nimi więź emocjonalna.

Sądy nie są surowe wobec sprawców przestępstw z art. 191a k.k. Zazwyczaj orzekana jest kara pozbawienia wolności z warunkowym zawieszeniem jej wykonania.

Jako przykład może posłużyć jeden ze stanów faktycznych. Sprawa o sygn. akt Ds. 86/12/D PR w Z.W. Oskarżony to 31-letni mężczyzna, który w okresie od listopada 2011 r. do stycznia 2012 r. w krótkich odstępach czasu z góry powziętym zamiarem uporczywie nękał swoją żonę. W mieszkaniu, które wspólnie zamieszkiwali, zamontował urządzenie podsłuchowe, a w sypialni - urządzenie rejestrujące obraz. W związku z tym kilkakrotnie utrwalił nagi wizerunek żony. Sąd uznał go za winnego i skazał na 80 stawek grzywny po 20 zł stawka. Obrońca oskarżonego wniósł apelację, zarzucając wyrokowi SR m.in. błąd w ustaleniach faktycznych mogący mieć wpływ na treść wydanego orzeczenia. SO w S. wyrokiem z dnia 13 marca 2013 r. uchylił zaskarżony wyrok i umorzył postępowanie karne o ten czyn. SO podzielił argumentację podniesioną $\mathrm{w}$ apelacji, m.in. stwierdzając, że nagrania zostały dokonane w trakcie trwania małżeństwa oskarżonego z pokrzywdzoną. Sąd zauważył, że należy zwrócić uwagę na motywację towarzyszącą oskarżonemu. Mianowicie jeszcze przed wytoczeniem procesu rozwodowego do oskarżonego docierały liczne, przeróżne informacje o niewierności żony. W związku ze złożonym pozwem to na nim ciążył obowiązek udowodnienia przed sądem zdrady małżeńskiej żony. Zatem oskarżony nie nagrywał swojej żony celem ośmieszenia jej, poniżenia bądź szantażowania, ale tylko i wyłącznie dla potwierdzenia swoich przypuszczeń i uzyskania dowodów. Oskarżony od 2010 r. nie mieszkał z żoną, więc miał ograniczone możliwości, aby uzyskać dowody w inny sposób. Mężczyzna nie rozpowszechnił tych nagrań i dobrowolnie je oddał w ręce organów ścigania. Sąd zwrócił także uwagę, że pokrzywdzona nie była świadoma zainstalowanych urządzeń, więc nie odczuwała negatywnego oddziaływania na jej sferę psychiczną. Taka droga, jaką zaprezentował SO, jest bardzo niebezpieczna, prowadzi bowiem do legalizacji zachowań, które są ewidentnie przestępne w przypadku, kiedy sprawca działa w celu zdobycia dowodu dla prowadzonego postępowania cywilnego. Motywacja sprawcy nie należy do zespołu ustawowych znamion czynu zabronionego z art. 191a k.k., czyli nie musi on działać w celu poniżenia czy szantażowania osoby pokrzywdzonej.

Podsumowując, należy stwierdzić, że przepis art. 191a k.k., który zakazuje utrwalania wizerunku nagiej osoby bądź osoby w trakcie czynności seksualnej przy użyciu w stosunku do niej przemocy, groźby bezprawnej czy podstępu, niewątpliwie stanowi rozszerzenie sfery ochrony wolności ludzi w zakresie przedmiotowym oraz zdecydowanie jest potrzebny. Na ile okaże się on użyteczny w praktyce dla zapo- 
biegania opisanych w nim zachowań oraz w ilu przypadkach będzie on podstawą pociągnięcia do odpowiedzialności karnej i ewentualnie jakie trudności będą się z tym wiązały, pokaże czas, po którego upływie możliwe będzie dokonanie kolejnych analiz przepisu art. 191a k.k.

\section{BIBLIOGRAFIA}

Bojarski T., [w:] Kodeks karny. Komentarz, red. T. Bojarski, Warszawa 2013.

Filar M., Kodeks karny. Komentarz, Warszawa 2015.

Królikowski M., Sakowicz A., [w:] Kodeks karny. Komentarz. Część szczególna, red. M. Królikowski, R. Zawłocki, t. 1, Warszawa 2013.

Marek A., Kodeks karny. Komentarz, Warszawa 2010.

Mozgawa M., [w:] Kodeks karny. Praktyczny komentarz, red. M. Mozgawa, Warszawa 2010.

Mozgawa M., Odpowiedzialność karna za bezprawne pozbawienie wolności (art. 165 k.k.), Lublin 1995.

Mozgawa M., Nazar-Gutowska K., Utrwalanie lub rozpowszechnianie wizerunku nagiej osoby - art. 191 k.k. (analiza prawnokarna i praktyka ścigania), [w:] Prawo w działaniu, red. M. Mozgawa, Warszawa 2014.

Nagość, www.sjp.pwn.pl/slowniki/nagość [dostęp: 01.05.2017].

Ustawa z dnia 5 listopada 2009 r. o zmianie ustawy - Kodeks karny i niektórych innych ustaw (t.j. Dz.U. z 2009 r., nr 206, poz. 1589).

Warylewski J., [w:] Kodeks karny. Część szczególna. Komentarz do art. 117-221, red. A. Wąsek, t. 1, Warszawa 2006.

Wyrok SN z dnia 16 lutego 1987 r., WR 28/87, OSNKW 1987, nr 9-10, poz. 85.

\section{SUMMARY}

The aim of this work is to analyze the crime of fixing and distributing the image of a naked person or a person during the sexual act. On the basis of the analysis, the author will answer the question whether the introduction of the offence referred to in Article 191a of the Polish Penal Code was necessary and appropriate, and additionally, whether - according to the legislator's assumptions - this regulation will counteract the increase of this phenomenon.

Keywords: image fixation; distributing; nudity; crime 